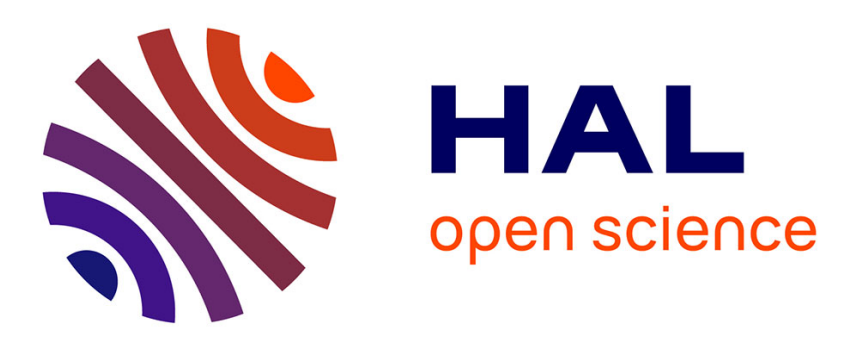

\title{
How to display social and environmental sustainability of food products?
}

\author{
Fatiha Fort, Laura Solaroli
}

\section{To cite this version:}

Fatiha Fort, Laura Solaroli. How to display social and environmental sustainability of food products?. Journal of Advanced Agricultural Technologies, 2018, 5 (2), pp.103-108. hal-02620248

\section{HAL Id: hal-02620248 \\ https://hal.inrae.fr/hal-02620248}

Submitted on 25 May 2020

HAL is a multi-disciplinary open access archive for the deposit and dissemination of scientific research documents, whether they are published or not. The documents may come from teaching and research institutions in France or abroad, or from public or private research centers.
L'archive ouverte pluridisciplinaire HAL, est destinée au dépôt et à la diffusion de documents scientifiques de niveau recherche, publiés ou non, émanant des établissements d'enseignement et de recherche français ou étrangers, des laboratoires publics ou privés. 


\title{
How to Display Social and Environmental Sustainability of Food Products?
}

\author{
Fatiha Fort and Laura Solaroli \\ INRA, Montpellier, France \\ Email: fatiha.fort@supagro.fr
}

\begin{abstract}
Sustainability concept has become an important subject in the people daily consumption. Therefore, many companies have changed their way of working to meet consumers' new expectations in terms of food impacts on the environment and society. In food market, consumers are considered as principal stakeholders and therefore the most important actors for the transition towards a more sustainable production. Moreover the issue of the sustainability of products and its eco-labeling has been raised in order to allow consumers to choose "sustainable" products. We propose in this article to evaluate the consumer behavior toward sustainable food products information. Sustainability is reflected in its environmental and social dimensions. An experiment results show that the information on sustainability brings additional value to the product. Social sustainability is becoming increasingly more important for consumers compared to environmental impacts. Results lead to recommendations about the way it will be suitable to display the product sustainability information.
\end{abstract}

Index Terms — food, sustainability, consumers, social impact, environmental impact

\section{INTRODUCTION}

The everyday consumption is still driven by habits, personal health concerns; prices [1] and consumers show in general resistance to changes [2]. In the latest ten years an ethical or responsible consumers emerged and started to purchase more organic and local food and to care more about the negative impacts of what they consume.

Through his daily actions, the consumer is considered as the main driver in adopting and conveying sustainable practices and thus participating in the performance of companies' sustainable development strategies [3]. As a result, many researchers have studied the key determinants of "green" product buying behaviors to identify relevant action variables for policy and business [4]. The main question remains: how to keep consumers informed about sustainability of food products? How could he identify sustainable food in supermarket shelves?

Many initiatives that have been implemented to inform about the sustainability of food products show the important economic stakes for companies and public policies and reveal the absence of a scientifically validated consensus around the criteria of sustainability

Manuscript received October 10, 2017; revised January 26, 2018. relevant to the consumer. For example, in France a large market experiment, involving 168 large enterprises, showed that consumers' preference goes to display formats that emphasize the simplicity, readability and immediate understanding of information.

Life Cycle Analysis (LCA) is particularly well suited to identify and measure environmental impact of production processes. The work on several products LCA assessment has been carried out with the objective of creating useful databases. As a consequence, users could identify and measure the impacts of their activities on the environment and choose the best alternatives [5]. Researchers apply the LCA method to social impacts and propose in the same way some indicators to assess the social and economic performances of production processes [6].

The results of the product LCA indicates the level of impact of different indicators that could then be displayed on food products.

We propose in this research to measure the willingness to pay for sustainable food products. The objectives of our research are to test the best way to display the environmental and the social impacts information on food products and to compare the WTP for products that display environmental and social impacts.

We will first present a literature review on the food eco-labeling, and then we will develop the methodology and end up with results, discussion and managerial recommendations.

\section{ENVIRONMENTAL ECO-LABELLING}

It is important to highlight that when we speak about sustainability we don't refer only to environmental friendly practices but also to social wellbeing and economic profit.

Therefore the sustainable consumption has to take into account all these actions. In the literature we can find terms such as "green" (or ecological) and "ethical" (or social) to show pro-environmental or pro-social consumption behavior. However, the green consumption behavior is also considered as a form of pro-social consumption behavior. In addition, the distinction between "ethical" and "green" is not always clearly defined [7]. Therefore, as affirmed in [8], the ecological/green dimension refers to practices dealing with the respect of the natural resources, the care for the livestock production condition, and the human quality of 
life. This approach concerns mostly the sustainable use and management of natural resources and the respect of the environment. The social dimension refers to the needs of the citizens, the work conditions and the support to the agro-food sector.

However the ethical consumerism, defined in [9], as "the purchase of a product that concerns an ethical issue", can involve practices to guarantee animal wellbeing, human right, work conditions, and fair trade but could also concern the environmental issue. The consumer actions are affected by different kind of motivations difficult to understand. The ethical consumer is in general a middle-class aged person with a higher income, average educated, well-informed and who has a prestigious job [4].

However, as emerged in different papers [10]-[9]-[11] even if consumers seems to be more concerned by the sustainable consumption, their actual behavior shows that attitude is not always followed by corresponding action [7]. Reference [10] investigates the presumed gap between the favorable attitude towards sustainable behavior and behavioral intention to purchase sustainable food products. In this paper [10] authors analyze the impact of involvement, perceived availability, certainty, perceived consumer effectiveness, value and social norms on consumer attitudes and intention towards sustainable food products. They argue, in contrast with [12], that positive attitudes towards sustainable consumption are not always followed by a positive intention.

The environmental attributes are well marked with eco-labels, or environmental labeling. The eco-labeling intends to make the consumer able to distinguish a product with environmental attributes compared to other similar products. Eco-labeling programs can also serve to heighten consumer awareness of environmental issues and of the implications of their choices. In countries where there is a high degree of consumer awareness, a trusted eco-label that provides reliable information on the environmental impacts of products in the marketplace in order to promote the selection of eco-labeled products. In countries where consumers are not as highly motivated by environmental concerns, eco-labeling can be used to promote environmentally beneficial actions.

Consumers are augmenting their desire to be informed, especially about credence attributes that are undetectable by the consumers (social and environmental impact), such as no child labor, the origin or the nature of product. Eco-labels carry messages to allow consumers to distinguish between two similar products because of its environmental attributes [13].

Therefore, in the case of sustainable development, which represents a credence attribute, consumers must trust either the producer or the label. Reference [14] sought to determine whether it is useful or not to put more labels (or logo) on a product. The question raised: is the intention to buy proportional to the number of labels? This question is interesting for our research because we want to test different sustainability attributes of food products. In their research, the authors highlighted the effect of inclusion, which is explained by a lower assessment of the weight of an attribute when multiple attributes are shown simultaneously on the product. As explained above, the results of previous research are not necessarily going in the same direction. Reference [9] Showed in their paper that there was a complementarity of labels that prevails over the redundancy and the information overload cited beforehand.

Thus, their results highlight that participants have a better attitude towards the product when it carries two labels (e.g. organic and Label Rouge). However, results don't change when a third label is added. However, it is important also to pay attention to the order in which labels are presented. Attitude and purchase intention can change. ${ }^{1}$ Overloading and redundancy of information is a problem that has been analyzed and has not led to a consensus either in the literature or in practice. Reference [15] describes the growing consumer confusion about the truthfulness and understanding towards the sustainable consumption. Indeed, too many logos' symbol are used and this matter reinforces the need for consistency and clearer representation of the product impacts. Reference [16] tests the impact of using a logo instead of a text to present environmental information. Their results show that the information presented clearly can make a significant difference in the evaluation of a product. This research partly justifies the fact that we also used indicators in our task to present the environmental and social information.

It seemed appropriate to test a logo containing all the environmental and social information together. For this we have taken into account a study in [17] where the author was interested in the understanding, in the use of sustainability labels on food products and in the motivation to buy these products. He explains that it is a lack of understanding on sustainable development that brings to low motivation and utilization towards sustainability labels. Thus, it may be worthwhile to compare different kind of information (indicators versus overall score) in order to see which generates greater motivation by measuring consumers WTP.

Finally, in terms of social classes, Grunert, [17] shows that higher social classes have a more important utilization of sustainable products. We used a similar methodology to develop a study on the understanding of several logos to identify, which one is better understood and then be able to propose the best way to display food sustainability.

The various studies presented have enabled us to establish which type of information to test, however, the valence (positive or negative) of the information presented has not been determined. Several studies have shown that negative indicators had a greater impact than positive indicators on a consumer who is interested on environmental issues. Consumers are more careful that things do not get worse, rather than make them better.

\footnotetext{
${ }^{1}$ The AB label (Agriculture Biologique) is presented before the LR label (Label Rouge), the increase in the attitude will be lower, while if the $\mathrm{LR}$ is presented before the $\mathrm{AB}$, this time the attitude is higher.
} 
Two psychological researches [18] and [19] have shown that people tend to be more sensitive to the fact of losing than winning. This supports the idea that individuals experiencing strong aversion to lose, and this has a greater impact on motivation. Reference [16] has validated these results in a study in which they compared the positive, negative and neutral valences of environmental information. In addition, negative information can greatly devalue the product, while positive information could increase its assessment but at a lower degree.

Our objective is to see how environmental impacts information influences the participants, willingness to pay. We could choose to give whether positive, neutral, or negative information. As literature shows different works on the negative information and our experiment aim to bring the producers to improve the sustainability of their products and of their production processes, we have chosen to only test the impact of positive information. We propose in this article to evaluate the consumer behavior towards sustainable food products information. Sustainability is reflected in its environmental and social dimensions.

\section{Methodology}

The ACYDU project funded by the National Research Agency (ANR) aims to develop methodologies for environmental, economic, social and territorial lifecycle analysis of processed foods. Three food products, emblematic for the French gastronomy, chosen for this project in order to identify the main obstacles and critical points of these food supply chains: the wine of Bourgogne, Foie Gras and Comte cheese. A laboratory experiment brought together 161 people who evaluated a sample of each product showing different information about its sustainability. We ask participants to indicate their Willingness to pay for different photos of the product (a bottle of Bourgogne wine, a jar of Foie Gras and a piece of Comte cheese).

Three indicators of environmental sustainability were selected in this phase: climate change, water pollution and depletion of resources. For social and territorial sustainability, we selected four indicators: workers wellbeing, promotion of the territory, ethics and creation of wealth. The experiment was conducted with 161 participants including 100 women and 61 men. The only criteria we considered for selecting our sample was that consumers had to buy and consume wine, cheese and foie gras. We had no restrictions on the age of participants, or their socio-professional level. The experiment took place in sensory laboratory in Montpellier. It consists of 16 boxes, and we could conduct the experiment on 16 people simultaneously. We implement different tasks. Each task showed the product and an additional information presented about its environmental and social impacts.

Considering the controversial discussion between legal authorities and enterprises about the nature of sustainability information, we provide information in two formats: multi-criteria scale format and an overall score (see Fig. 1) for social and environmental impacts. For the two formats we choose to provide positive evaluation of the product on the environment and social aspects.

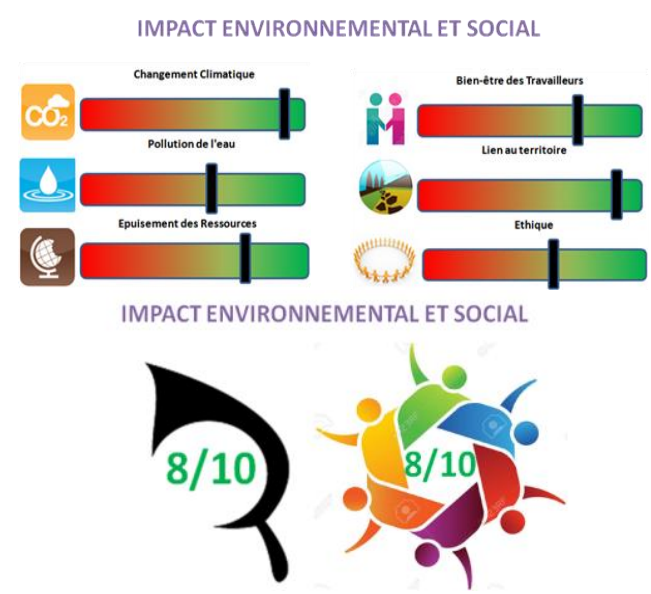

Figure 1. The two formats of environmental and social impacts

In total each participant performed 5 tasks and propose a price for each product.

Task 1: the photo of each of the products without information.

Task 2: the photos and logo on environmental labeling with multi-criteria scales.

Task 3: show the logo on environmental labeling with an overall score.

Task 4: provide information on the social sustainability and show a logo on each product scale.

Task 5: give the info with a logo on the social sustainability via an overall scale.

To measure the willingness to pay, we give first the average market price range of a each piece of the product in the photo. Participants had to position the cursor on the price they were willing to pay for the product.

The screen showed a task page, and the participants had to answer questions directly on the computer. The order of tasks was randomized. Finally, we asked to participants some personal information.

\section{RESUltS}

Table I presents the WTP for products presented (photo) without any information.

TABLE I. WTP FOR THE PRODUCT WITHOUT ANY INFORMATION

\begin{tabular}{|l|c|c|}
\hline & Mean WTP $(€)$ & SD \\
\hline Wine & 6,52 & 2,14 \\
\hline Foie Gras & 20,04 & 3,48 \\
\hline Comte cheese & 3,08 & 0,51 \\
\hline
\end{tabular}

The first overall results are that for the three products information about sustainability brings positive added value comparing to the blinded product (Fig. 2).

We can observe that the evaluation of a product with sustainability differ from environment and social information and from the format scale or overall score (all differences are significant at $\mathrm{p}<0,001$, Table II). 


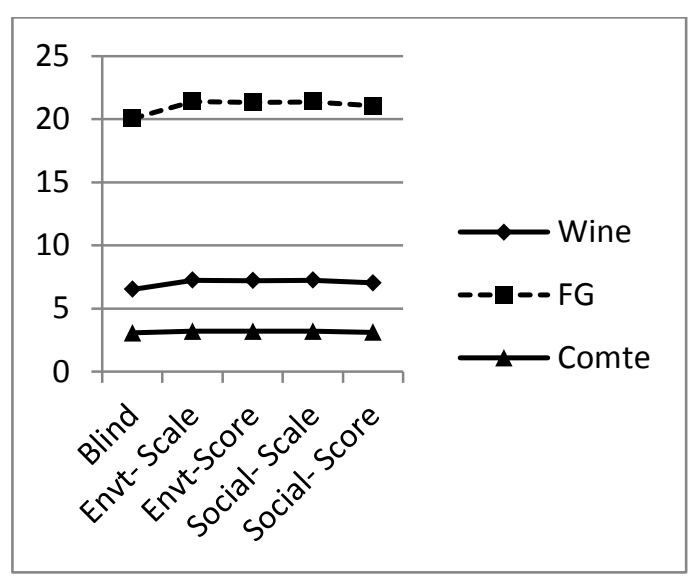

Figure 2. WTP for environmental and social impacts

TABLE II. T TEST OF WTP DIFFERENCES WITH THE BLINDED PRODUCT

\begin{tabular}{lcccc}
\hline \multicolumn{1}{c}{ Wine } & Mean & SD & $\begin{array}{c}\text { t (the gap with } \\
\text { blind })\end{array}$ & $\mathrm{P}$ \\
\hline Blind & 6,52 & 2,13 & & \\
Envt-Scale & 7,24 & 2,1 & 5,35 & 0,000 \\
Envt- Score & 7,21 & 1,98 & 6,82 & 0,000 \\
Social-Scale & 7,24 & 2,00 & 5,94 & 0,000 \\
Social-Score & 7,03 & 1,96 & 4,53 & 0,000 \\
\hline
\end{tabular}

\section{A. Environmental Impacts}

Comparing only environmental tasks between the overall score and the multicriteria scales (Table III), we can observe that the better valorization of the information is different from one product to another. For Comte cheese and the wine product there are no significant differences between the two formats. However, for Foie Gras the format scale appears to be more influent on consumer's WTP.

TABLE III. WTP FOR TWO FORMAT OF ENVIRONMENTAL IMPACTS INFORMATION

\begin{tabular}{|c|c|c|c|c|c|c|}
\hline & \multicolumn{2}{|c|}{ Wine } & \multicolumn{2}{c|}{ Foie Gras } & \multicolumn{2}{c|}{ Comte } \\
\hline & $\begin{array}{c}\text { Envt- } \\
\text { Scale }\end{array}$ & $\begin{array}{l}\text { Envt- } \\
\text { Score }\end{array}$ & $\begin{array}{l}\text { Envt- } \\
\text { Scale }\end{array}$ & $\begin{array}{c}\text { Envt- } \\
\text { Score }\end{array}$ & $\begin{array}{c}\text { Envt- } \\
\text { Scale }\end{array}$ & $\begin{array}{c}\text { Envt- } \\
\text { Score }\end{array}$ \\
\hline Mean & 7,24 & 7,21 & 21,4 & 21,32 & 3,21 & 3,13 \\
\hline SD & 2,1 & 1,98 & 3,47 & 3,57 & 0,5 & 0,48 \\
\hline T & \multicolumn{2}{|c|}{0,284} & \multicolumn{2}{c|}{6,34} & \multicolumn{2}{c|}{0,73} \\
\hline P & \multicolumn{2}{|c|}{0,777} & \multicolumn{2}{c|}{0,000} & \multicolumn{2}{c|}{0,47} \\
\hline
\end{tabular}

\section{B. Social Impacts}

As the social impacts tasks are concerned we can observe that the results are quite different. We compare the WTP for social impacts with two formats: multicriteria scale and overall score. The results presented in Table IV show that in all cases the scale format provide a better value than the overall score.

We can conclude that for environment impact information, the format does not mind for consumers, but for social impacts consumers prefer multicriteria information. These results could be linked to the fact that the indicators of environment impacts are so difficult to understand. Indeed, the climate change, water pollution and depletion of resources could be not clear for consumer so they use a holistic way to assess the positive impacts. For social impacts indicators, i.e. workers wellbeing, promotion of the territory, ethics and creation of wealth, seemed to be more familiar and easier to understand and they can better valorize this analytical information.

TABLE IV. WTP FOR TWO FORMAT OF SOCIAL IMPACTS INFORMATION

\begin{tabular}{|c|c|c|c|c|c|c|}
\hline & \multicolumn{2}{|c|}{ Wine } & \multicolumn{2}{c|}{ Foie Gras } & \multicolumn{2}{c|}{ Comte } \\
\hline & $\begin{array}{c}\text { Social } \\
\text {-Scale }\end{array}$ & $\begin{array}{c}\text { Social- } \\
\text { Score }\end{array}$ & $\begin{array}{c}\text { Social-S } \\
\text { cale }\end{array}$ & $\begin{array}{c}\text { Social- } \\
\text { Score }\end{array}$ & $\begin{array}{c}\text { Social- } \\
\text { Scale }\end{array}$ & $\begin{array}{c}\text { Socia } \\
1- \\
\text { Score }\end{array}$ \\
\hline Mean & 7,24 & 7,03 & 21,36 & 21,05 & 3,19 & 3,13 \\
\hline SD & 2,00 & 1,96 & 3,57 & 3,38 & 0,49 & 0,48 \\
\hline $\mathrm{t}$ & \multicolumn{3}{|c|}{2,64} & \multicolumn{2}{|c|}{2,22} & \multicolumn{2}{c|}{3,11} \\
\hline $\mathrm{p}$ & 0,009 & \multicolumn{2}{c|}{$0,028 *$} & \multicolumn{2}{c|}{0,002} \\
\hline$* 0,05$
\end{tabular}

\section{Environmental vs Social Impacts}

Comparing the average scores of the environmental and social tasks we seek to assess which bring the better valorization of the information. As the format of information is important, we compared the environment and social impacts information in the same way (Table $\mathrm{V})$.

TABLE V. WTP FOR ENVIRONMENTAL AND SOCIAL IMPACTS INFORMATION PRESENTED BY A SCALE

\begin{tabular}{|l|c|c|c|c|c|c|}
\hline & \multicolumn{2}{|c|}{ Wine } & \multicolumn{2}{c|}{ Foie Gras } & \multicolumn{2}{c|}{ Comte } \\
\hline & $\begin{array}{l}\text { Envt- } \\
\text { Scale }\end{array}$ & $\begin{array}{l}\text { Social } \\
\text {-Scale }\end{array}$ & $\begin{array}{l}\text { Envt- } \\
\text { Scale }\end{array}$ & $\begin{array}{l}\text { Social- } \\
\text { Scale }\end{array}$ & $\begin{array}{l}\text { Envt- } \\
\text { Scale }\end{array}$ & $\begin{array}{l}\text { Social } \\
\text {-Scale }\end{array}$ \\
\hline Mean & 7,24 & 7,24 & 21,4 & 21,36 & 3,18 & 3,19 \\
\hline SD & 2,1 & 2,00 & 3,47 & 3,57 & 0,48 & 0,49 \\
\hline $\mathrm{t}$ & \multicolumn{2}{|c|}{0.006} & \multicolumn{2}{|c|}{6,34} & \multicolumn{2}{c|}{2,22} \\
\hline $\mathrm{p}$ & \multicolumn{2}{|c|}{0.99} & \multicolumn{3}{c|}{0,000} & \multicolumn{2}{c|}{$0,028^{*}$} \\
\hline$p<0,05 \%$
\end{tabular}

For wine product there is no significant differences between environment vs social information. The same valorization is observed. For Foie Gras the environmental aspect is more valorized and for Comte the social aspect is valorized.

If we consider this comparison based on an overall score indicator, we can draw different conclusions (Table VI).

TABLE VI. WTP FOR ENVIRONMENTAL AND SOCIAL IMPACTS INFORMATION PRESENTED BY AN OVERALL SCORE

\begin{tabular}{|l|c|l|l|l|l|l|}
\hline & \multicolumn{2}{|c|}{ Wine } & \multicolumn{2}{c|}{ Foie Gras } & \multicolumn{2}{c|}{ Comte } \\
\hline & $\begin{array}{l}\text { Envt- } \\
\text { Score }\end{array}$ & $\begin{array}{l}\text { Social- } \\
\text { Score }\end{array}$ & $\begin{array}{l}\text { Envt- } \\
\text { Score }\end{array}$ & $\begin{array}{l}\text { Social- } \\
\text { Score }\end{array}$ & $\begin{array}{l}\text { Envt- } \\
\text { Score }\end{array}$ & $\begin{array}{l}\text { Social- } \\
\text { Score }\end{array}$ \\
\hline Mean & 7,21 & 7,03 & 21,32 & 21,05 & 3,21 & 3,13 \\
\hline SD & 1,98 & 1,96 & 3,57 & 3,38 & 0,5 & 0,48 \\
\hline T & \multicolumn{2}{|c|}{1,976} & \multicolumn{2}{c|}{2,22} & \multicolumn{2}{c|}{0,73} \\
\hline P & \multicolumn{2}{|c|}{0,05} & \multicolumn{2}{c|}{0,028} & \multicolumn{2}{c|}{0,47} \\
\hline
\end{tabular}


For wine and Foie Gras the environmental impact seems to be significantly better valorized by a greater WTP. For Comte cheese there is no differences between social vs environmental impacts.

In some we can conclude that for wine product environment impact is more valorized by consumers if it is presented with an overall score. Indeed wine is perceived as using pesticides and other chemicals additives so consumers are seeking for more clean product. The Foie Gras carries a very bad image according to the animal welfare aspects and the manner in which duck breeding is conducted. So consumers might be aware about environmental aspect regardless of the format. Comte cheese is the first French PDO in terms of volumes and consumers consider that this terroir product is enough sustainable without any more information.

\section{General CONCLUSION}

Objectives of this article were: to identify the best way to inform consumers about the sustainability of food product and to propose some avenues for academic research and recommendations for professionals.

Consumer food habits and preferences are shaped by cultural traditions, norms, fashion, and physiological needs, as well as by personal food experience. The consumer is also influenced by information provided by producers and distributors.

The experiment conducted in this article allows deepening previous research about the consumer's behavior toward sustainable food product [1]-[20].

The main result of this research is that the sustainable information about a product brings added value compared to no information. This result is in line of previous research in marketing theory [21], [22]. We show also than the way that consumer prefers the sustainable information is different according to his capacity to understand all the indicators provided. This result is very important because the product Life Cycle Analysis is based on scientific indicators that could not be easy to be translated into behavior by the consumer. Our results show, in the case of environment impacts, that an overall score is preferred than a multicriteria scale. At the opposite for social impact the scale is better understood because the indicators are familiar for the consumers.

Results suggest than the format of the provided information about the sustainability varies among products. For example for wine product, consumers do not make any differences between environment and social impacts if the information is provided by scales. In the opposite, for Comte cheese in the case of overall score format consumers do note differentiate between environmental and social impacts.

Finally we confirm that when buying, taking into account the social or environmental dimension is a responsible purchase and shows that the individual takes into account the public consequences of his private consumption. He uses its purchasing power to induce changes in society [10]. Our results suggests that the way information provided should be in an understandable language and very easy to use for differentiating products on the supermarkets shelves. There is therefore a real stake in environmental and social information as a lever to adopt more sustainable practices.

\section{ACKNOWLEDGMENT}

This research is part of the Acydu research project that has been financed by French Research National Agency (ANR 12-ALID-0002).

\section{REFERENCES}

[1] L. Reisch, U. Eberle, and S. Lorek, "Sustainable food consumption: An overview of contemporary issues and policies," Sustainability: Science, Practice \& Policy, vol. 3, 2013.

[2] S. Lahlou, "L'exploration des représentations sociales à partir des dictionnaires," Méthodes D'étude des Représentations Sociales, pp. 37-58, 2005.

[3] A. Béji-Bécheur and N. Özçaglar-Toulouse, "Institutionnalisation du développement durable et émergence d'un marketing durable," Recherche Et Applications En Marketing, vol. 29, no. 3, pp. 3-9, 2014.

[4] H. R. Kaufmann, M. F. A. K. Panni, and Y. Orphanidou, "Factors affecting consumers' green purchasing behavior: An integrated conceptual framework," Amfiteatru Economic, vol. 9, no. 31, February 2012.

[5] C. Rizet, E. Cornélis, M. Browne, and J. Léonardi, "GHG emissions of supply chains from different retail systems in Europe," Procedia Social and Behavioral Sciences, vol. 2, pp. 6154-6164, 2010.

[6] A. Jørgensen, I. T. Hermann, and J. B. Mortensen, "Is LCC relevant in a sustainability assessment?" International Journal of Life Cycle Assessment, vol. 15, no. 6, pp. 531-532, 2010.

[7] A. Krystallis, M. Vassallo, G. Chryssohoidis, and T. Perrea, "Societal and individualistic drivers as predictors of organic purchasing revealed through a portrait value questionnaire (PVQ)based inventory," Journal of Consumer Behaviour, vol. 7, no. 2, pp. 164-187, 2008.

[8] I. Vermeir and W. Verbeke, "Sustainable food consumption among young adults in Belgium: Theory of planned behavior and the role of confidence and values," Ecological Economics, pp. 1$12,2006$.

[9] P. D. Pelsmacker, L. Driesen, and G. Rayp, "Do consumers care about ethics? Willingness to pay for fair-trade coffee," The Journal of Consumer Affairs, vol. 39, no. 2, pp. 363-385, 2005,

[10] F. E. Webster, "Determining the characteristics of the socially conscious consumer," Journal of Consumer Research, vol. 2, pp. 188-196, 1975.

[11] M. Hume, "Compassion without action: Examining the young consumers consumption and attitude to sustainable consumption," Journal of World Business, vol. 45, no. 4, pp. 385-394, 2010.

[12] I. Dufeu, J. M. Ferrandi, P. Gabriel, and M. L. Gall-Ely, "Socioenvironmental multi-labelling and consumer willingness to pay," Recherche et Applications en Marketing, July 2014.

[13] H. Karl and C. Orwat, "Environmental labelling in Europe: European and national tasks," Environmental Policy and Governance, pp. 212-220, 1999

[14] E. Jongmans, A. Jolibert, and J. Irwin, "Toujours plus, toujours mieux? Effet contre-intuitif de l'évaluation des attributs environnementaux du produit par le consommateur," Recherche et Applications en Marketing, vol. 29, no. 3, pp. 10-33, 2014.

[15] G. Bounds, "As eco-seals proliferate, so do doubts," Wall Street Journal, p. D1, April 2009.

[16] N. Borin, D. C. Cerf, and R. Krishnan, "Consumer effects of environmental impact in product labeling," Journal of Consumer Marketing, vol. 28, no. 1, pp. 76-86, 2011.

[17] K. G. Grunert, "Food quality and safety: Consumer perception and demand," European Review of Agricultural Economics, vol. 32, no. 3, pp. 369-391, September 2005.

[18] A. Tversky and D. Kahneman, "The framing of decisions and the psychology of choice," Science, vol. 211, 1981. 
[19] A. Tversky and D. Kahneman, "Prospect theory: An analysis of decision under risk," Econometrica, vol. 47, no. 2, pp. 263-291, 1979.

[20] W. Martindale, "Using consumer surveys to determine food sustainability," British Food Journal, vol. 116, no. 7, pp. 11941204, 2014.

[21] J. W. Alba and J. W. Hutchinson, "Dimensions of consumer expertise," The Journal of Consumer Research, vol. 13, no. 4, pp. 411-454, March 1987.

[22] M. Fishbein and I. Ajzen, "Belief, attitude, intention and behaviour: An introduction to theory and research," Philosophy \& Rhetoric, vol. 41, no. 4, p. 573, 1975.

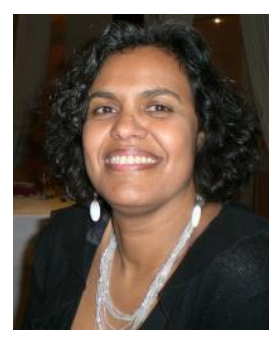

Fatiha Fort obtained a PhD in Management Sciences at the University of Montpellier in 2005. Currently she is full professor in marketing management at SupAgro Montpellier. She is a member of the MOISA Research Unit and her research focuses on consumer behavior toward sustainable food. She published many papers in the field of marketing of food products and territories. She is the editor of Systèmes Alimentaires / Food Systems Review.

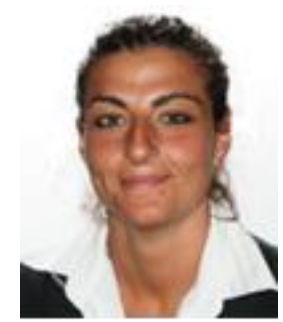

Laura Solaroli obtained a PhD in Agro-foord Policy and Economics at the University of Bologna in 2014. In 2014/2015, she was a post-doctoral fellow at the MOISA Research Unit in Montpellier and her research focuses on consumer behavior toward sustainable food. She did some consulting for the World Food Program (United Nations) on Food Security projects. Currently, she is project leader on agro-food standardization at AFNOR and occasionally, she gives lessons on the Food Security issue at the University of Montpellier. 